\title{
PRINCIPLES OF FUNGAL TAXONOMY
}




\section{PRINCIPLES OF FUNGAL TAXONOMY}

P. H. B. TALBOT, Ph.D. (London)

Reader in Mycology

Waite Agricultural Research Institute

University of Adelaide

South Australia

Macmillan Education 
ISBN 978-o-333-11564-o ISBN 978-1-349-15432-6 (eBook) DOI 10.1007/978-1-349-15432-6

(C) P. H. B. Talbot $197 \mathrm{I}$

Reprint of the original edition 1971

All rights reserved. No part of this publication may be reproduced or transmitted, in any form or by any means, without permission.

First published I97I

Published by

THE MACMILLAN PRESS

London and Basingstoke

Associated companies in New Tork Toronto

Dublin Melbourne Fohannesburg and Madras

SBN 333 II 56 I 9 (cased)

$333 \div 15643$ (paper) 


\section{ACKNOWLEDGMENTS}

I should like to thank my colleagues, Dr J. H. Warcup, Dr B. G. Clare and $\mathrm{Mr}$ J. A. Simpson, for kindly reading drafts of this book and making many helpful suggestions for its improvement; $\mathrm{Mr} \mathrm{B}$. A. Palk for photographing the illustrations; and Dr G. C. Ainsworth for his friendly encouragement.

Where I have quoted from publications or copied illustrations, the sources are cited in the text, but in addition I would like to record my thanks to the several authors and publishers who have kindly permitted the use of copyright material: The Rockefeller University Press for the use of a quotation from an article in the Fournal of Cell Biology by Dr G. F. Robinow; Pergamon Press for material which appeared in Soil Fungi and Soil Fertility by Dr S. D. Garrett; Academic Press for a quotation from Plant Diseases: Epidemics and Control by Dr J. E. Van der Plank; The University of Minnesota Press, Minneapolis, for material which appeared in The Molds and Man by Dr C. M. Christensen; University of Chicago Press for material from an article in Botanical Gazette by Dr G. W. Martin; The International Association for Plant Taxonomy for a quotation from an article by Dr A. Munk which appeared in Taxon, and for extensive quotations from an article of my own in Taxon; The Editors of the British Mycological Society Transactions and The Naturalist for permitting quotations from articles by Mr E. W. Mason; The Systematics Association for material which appeared in an article by Dr A. D. J. Meeuse in the Association's Publication No. 6; The Colston Research Society for permitting me to quote from an article by Dr P. H. Gregory, and to copy an illustration by Dr M. F. Madelin, which appeared in The Fungus Spore; The New York Botanical Garden for allowing me to make a line drawing from a photograph by Dr D. I. Fennell and Dr J. H. Warcup which appeared in Mycologia.

I am much indebted to the Chief of the Botanical Research Institute, Pretoria, to Dr O. Vaartaja and to Dr Elaine Davison for allowing me to make line drawings from photographs in their possession. 


\section{FOREWORD}

The aim of this book is to give a concise account of fungi, suitable for a short undergraduate course in mycology. The main problem with such a course is to condense the material into a balanced account, limited enough to fit the time yet broad enough to avoid triviality. I do not believe that this problem should be met by treating interesting general topics - and mycology abounds in these - within a framework of taxonomic groupings. However much one may deny it, students then gain the false impression that one's whole object is to teach life-cycles and systematics, and that a particular classification is either sacrosanct and permanent or at least better than others. The question, 'Better for what purpose?' is seldom raised.

As a practising taxonomist I do not decry taxonomy - far from it! But it is realistic to suppose that most students have little interest in a course that stresses formal classification, however unintentionally. Taxonomic knowledge comes by experience, not by the purgatory of memorizing a catalogue of names, diagnoses and keys. Most professional taxonomists are drawn into this field at a graduate level or later, by their own desire and efforts. The groundwork required is a broader view of fungi; the amount of classification given need be only enough to achieve precise communication and to connect topics. The balance is nevertheless difficult to strike. Seeing that science does not consist in gathering facts for their own sake, but rather in reasoning from observations, forming hypotheses and testing them, I believe that classification should be approached as the logical groupings arising out of comparative morphology and other studies; it should be the hypothesis which seeks to express the order to be found among the great diversity of fungal forms. This at least is the ideal even if in practice classification often becomes merely a catalogue of knowledge about fungal forms.

I consider that knowledge of the ways in which fungal classification may be built up is more important than a detailed survey of the taxa themselves. My object here has thus been to stress morphology and terminology in the first place - because they are basic to communication about fungi - and to use this knowledge at every appropriate stage to show how classification is 
arrived at. It is in this sense that $I$ use the phrase 'principles of fungal taxonomy' as the title of this book, hoping that prospective readers will not be misled into expecting something more sophisticated. I have tried to introduce, and expand upon, a thread of classification throughout the book until the principal taxa are apparent and it then becomes clumsy and uneconomical to continue using this approach. At this stage it is inevitable that the taxa should be treated more formally, but not necessarily to the same level in each group studied. In general, the level selected and the examples studied serve the purpose of illustrating particular points to be made; for example, some taxonomic principle, biological diversity and versatility, or economic importance.

In stressing morphology, I realize that a descriptive catalogue of structures may be just as boring as one of fungal taxa unless it can be brought alive by relating structure to function and habitat. To do this at all adequately requires time and space, and a treatment of fungal physiology beyond the scope of this book; nevertheless, some attempt has been made to solve this problem. At first sight the emphasis on terminology may appear oppressive; but I consider it to be vital for precise communication and, as it is reinforced in practical periods, it has not, in fact, proved a serious obstacle to most students.

The general philosophy and principles of taxonomy are lively topics which can be relied upon to cause much interest and controversy among biologists. They should be introduced to students at an early stage, but are seldom mentioned. I thought it useful to give a brief account of some of these aspects (Chapters 2 and 3) before beginning to discuss fungi in detail. It is intended that these chapters should be browsed over originally, and perhaps re-read at a later stage.

I have not attempted to cite literature references for each statement made or section of the work covered, but have done so when necessary for developing an argument in the text. By doing this it may appear that $I$ have not given credit where it is undoubtedly due. However, I am deeply aware that this book is a compilation in which my share has been to summarize, review or re-arrange the discoveries and thoughts of other mycologists. It is something like the method of Professor McGinty (Lloyd, I913) who made all his notable discoveries and 'new combinations' seated at the top of a library ladder with a large book in his lap.

Most of the repetition which occurs in this text is deliberate, but I hope not excessive. A student, unlike a reviewer, does not read from cover to cover in a short time and thus needs to be reminded of certain facts which, although mentioned before, become appropriate again in a somewhat different context. I believe that this reinforcement of ideas and facts is necessary and also that it is helpful if the various chapters are more or less self-contained.

With a few minor changes, the broad classification adopted in this text is that of Ainsworth (1966). 
While this book does not contain any practical exercises, it may be useful to state what I believe should be the aims of laboratory periods in an introductory course. These should not be primarily to train students to recognize and classify various types of fungi, although some knowledge of this kind will certainly be acquired incidentally. Practicals should instead be devoted to: observing and recording accurately what is seen; comparing fungi or parts of fungi in various ways, and writing down the comparisons; seeing the morphological structures mentioned in lectures and arousing curiosity about their functions; seeing living fungi in action; and reasoning from observations. These are the tools used in practical applications of mycology and are also the basis of taxonomy.

P.H.B.T.

Adelaide, South Australia, I969. 


\section{CONTENTS}

I. INTRODUGTION: ON THE NATURE AND IMPORTANGE OF FUNGI

2. SYSTEMATIGS, TAXONOMY AND

NOMENGLATURE

Systematic study of fungi

Relationship between systematics, taxonomy and nomenclature

Nomenclature

3. TAXONOMIG PROBLEMS ASSOGIATED WITH VARIATION IN FUNGI

Species concepts

4. MORPHOLOGY OF SOMATIG STRUGTURES

The thallus

The hypha

The fungal cell

Nuclear complement and nuclear behaviour

Specialized somatic structures

Aggregations of hyphae: tissues

Mycorrhizas

66

Mycangia

68

Taxonomic implications of somatic structures

5. REPRODUGTION IN FUNGI: GENERAL

Asexual, sexual and parasexual reproduction contrasted

Sporophores

Spores

Pleomorphism 
6. ASEXUAL REPRODUGTION 86

Types of asexual reproduction $\quad 86$

Taxonomic implications of asexual reproduction $\quad 88$

7. SEXUAL REPRODUGTION 9o

The sexual cycle 90

Types of sexual anastomosis concerned in plasmogamy $\quad 9^{\mathbf{r}}$

Sex and sexual compatibility: heterothallism 94

Taxonomic implications of sexual reproduction $\quad 96$

8. FUNGI WITH A PLASMODIAL THALLUS

DIVISION MYXOMYGOTA: SLIME-MOULDS 99

Myxomycetes Ioo

Plasmodiophoromycetes $\quad 106$

Colonial slime-moulds: Labyrinthulales and Acrasiales $\quad 107$

9. FUNGI WITH SPORANGIA: EUMYGOTA

SUBDIVISIONS MASTIGOMYCOTINA AND ZYGOMYGOTINA

Mastigomycotina $\quad$ I IO

Chytridiomycetes 112

Oomycetes 115

Zygomycotina $\quad 122$

Zygomycetes 122

Io. FUNGI WITH A STERILE MYGELIUM OR GONIDIA: EUMYGOTA SUBDIVISION

DEUTEROMYGOTINA

Sterile mycelia $\quad$ I33

Conidia and conidiophores $\quad$ I34

Aggregation of conidiophores in compound sporophores $\quad$ I4O

$\begin{array}{ll}\text { Classification of Deuteromycotina } & 147\end{array}$

$\begin{array}{lr}\text { Host specificity } & \text { I49 }\end{array}$

II. FUNGI WITH ASGI AND ASGOSPORES IN FRUITBODIES: EUMYGOTA SUBDIVISION ASCOMYGOTINA

Asexual reproduction $\quad$ I5O

Sexual reproduction $\quad$ I5 I

Ascocarps and their development

$\begin{array}{ll}\text { Asci and ascospores } & \text { I } 59\end{array}$ 
Taxonomic implications $\quad$ I62

Hemiascomycetes $\quad{ }_{16} 6_{3}$

Plectomycetes $\quad$ I66

Pyrenomycetes $\quad$ I 7 I

Discomycetes 181

$\begin{array}{ll}\text { Loculoascomycetes } & \text { I } 88\end{array}$

$\begin{array}{lc}\text { Lichens } & 192\end{array}$

12. FUNGI WITH BASIDIA AND BASIDIOSPORES IN FRUITBODIES: EUMYGOTA SUBDIVISION BASIDIOMYGOTINA

Mycelium, hyphae and hyphal systems $\quad$ I94

Clamp connexions $\quad$ I95

Reproduction and formation of basidiocarps $\quad$ 196

Hymenium $\quad 202$

Basidia $\quad 204$

Discharge of basidiospores $\quad 208$

Taxonomic implications $\quad 209$

$\begin{array}{ll}\text { Teliomycetes } & 214\end{array}$

Phragmobasidiomycetes $\quad 222$

Holobasidiomycetes $\quad 223$

13. MORPHOLOGIGAL SIMILARITIES IN FUNGI 242

Some general attributes of hyphae 243

Similarities in microscopic features $\quad 243$

Similarities in macroscopic features $\quad 251$

REFERENGES 253

$\begin{array}{ll}\text { INDEX } & 262\end{array}$ 